\title{
Laboreal
}

Volume 15 N$^{\circ} 2$ | 2019

Varia

\section{O mundo do trabalho em (re)análise : um olhar a partir da psicodinâmica do trabalho}

El mundo del trabajo en (re)análisis : una mirada desde la psicodinámica del trabajo

Le monde du travail en (re)analyse : regard sur la psychodynamique du travail The world of work in (re)analysis: a view from the psychodynamics of work

\section{João Areosa}

\section{OpenEdition}

\section{Journals}

\section{Edição electrónica}

URL: http://journals.openedition.org/laboreal/15504

DOI: $10.4000 /$ laboreal. 15504

ISSN: 1646-5237

\section{Editora}

Universidade do Porto

\section{Refêrencia eletrónica}

João Areosa, " $\mathrm{O}$ mundo do trabalho em (re)análise : um olhar a partir da psicodinâmica do trabalho », Laboreal [Online], Volume 15 No2 | 2019, posto online no dia 01 dezembro 2019, consultado o 10 abril 2020. URL : http://journals.openedition.org/laboreal/15504; DOI : https://doi.org/10.4000/laboreal. 15504

Este documento foi criado de forma automática no dia 10 abril 2020.

\section{(c) (1) (8)}

Laboreal está licenciado com uma Licença Creative Commons - Atribuição-NãoComercial 4.0 Internacional. 


\title{
O mundo do trabalho em (re)análise : um olhar a partir da psicodinâmica do trabalho
}

\author{
El mundo del trabajo en (re)análisis : una mirada desde la psicodinámica del \\ trabajo \\ Le monde du travail en (re)analyse : regard sur la psychodynamique du travail \\ The world of work in (re)analysis: a view from the psychodynamics of work
}

João Areosa

\section{NOTA DO EDITOR}

Manuscrito recebido em julho/2018

Aceite após peritagem novembro/2019

\section{Introdução}

1 Os efeitos do trabalho sobre a saúde mental são ainda um campo relativamente pouco considerado, apesar que já existirem algumas décadas de investigação sobre esta temática. $\mathrm{Na}$ realidade, estamos ainda longe de conhecer o verdadeiro alcance e influência que o trabalho nos pode provocar, quer seja nos benefícios que oferece, quer seja nos aspetos prejudiciais que suscita, quer ainda, como um misto de ambas as situações. Talvez, na maioria das vezes, o trabalho implique isso mesmo: um misto entre aspetos positivos e negativos.

2 Obviamente que a saúde mental depende de múltiplos fatores (incluindo do nosso modelo económico - capitalismo), mas nunca podemos esquecer a variabilidade pessoal de cada membro da sociedade. Por isso, uma determinada situação pode ser entendida ou sentida como negativa para determinados indivíduos e, pelo contrário, pode ser 
vista como positiva para outros. Naturalmente que isto acaba por complexificar bastante a forma como podemos interpretar aquilo que afeta a saúde mental. Assim, quando ao longo do texto se fizer alusão - de modo aparentemente simplista - à relação trabalho/saúde mental deve considerar-se que esta ligação está entrelaçada por aspetos multidimensionais, decorrente de fatores biopsicossociais. Logo, não há uma relação determinista entre trabalho e adoecimento. São as múltiplas e diversificadas interações entre o trabalhador, o seu coletivo de trabalho e a organização do trabalho que podem proteger ou degradar a saúde mental. E nesta teia complexa de interações há uma espécie de coexistência ou "confronto" entre fatores protetores e não-protetores (deteriorantes) da saúde mental. A vivência nunca é monolítica.

O presente artigo pretende apresentar algumas das principais ideias discutidas na perspetiva da psicodinâmica do trabalho, estruturando-se na extensa literatura sobre o tema. Ao longo do texto será debatida a saúde mental relacionada ao trabalho, sabendo que este é o ponto de ancoragem desta disciplina (Sznelwar, 2015). A seleção da bibliografia foi efetuada, entre outras fontes, a partir de diversas pesquisas em bases de dados, seminários no âmbito da temática ou, pontualmente, através de contatos pessoais. Esta área de conhecimento surgiu há pouco mais de 25 anos e teve como principal mentor Christophe Dejours. Apesar da discussão sobre a relação entre trabalho e saúde mental ser mais ampla (em termos de modelos e perspetivas) a psicodinâmica do trabalho acaba por incorporar diversos saberes de outras disciplinas científicas e isso permitiu-lhe desenvolver uma análise extraordinariamente pertinente sobre o seu objeto de estudo. É exatamente por isso que a utilizámos como principal referencial.

\section{Capitalismo : um travão para a humanização do trabalho}

4 Os diversos fatores que estiveram na génese do capitalismo, preconizados por Max Weber (2001), são bastante diferentes daqueles que podemos observar na atualidade. Segundo Richard Sennett (2001) houve uma rutura significativa entre o velho capitalismo de classe e o novo capitalismo flexível. As consequências desta transformação foram, no mínimo, aterradoras para algumas formas de interação e convivência contemporâneas, incluindo ao nível do trabalho. o lucro tornou-se, cegamente, no único objetivo das empresas (ou pelo menos o principal) e a ideologia utilitarista foi levada ao extremo, tendo em conta que os meios utilizados para atingir esse fim (lucro) são, em certos casos, imorais. Foi também por isso que no mundo atual do trabalho as pessoas se tornaram descartáveis e este tipo de práticas originou um verdadeiro batalhão de trabalhadores precários e um exército de desempregados. A pobreza e a exclusão alastram-se num mundo de crescente produção e abundância, pois nunca tantos recursos estiveram tão concentrados - e assimetricamente distribuídos - na história da humanidade. O capital passou a ter um valor superior ao próprio Homem. Esta afirmação não é exagerada se considerarmos que a hegemonia financeira dos mercados de capital empurra para a miséria largas camadas da população em diversos países. As consequências negativas para a qualidade de vida das populações são demasiado evidentes, mas os efeitos que estas situações acarretam para a saúde/sanidade mental dos indivíduos e para a sua própria identidade estão, ainda hoje, longe de ser totalmente compreendidas. 
5 A forma como estamos a gerir politicamente as nossas sociedades levanta alguns paradoxos, os quais só encontram explicação na "irracional" procura do lucro. Vejamos apenas dois exemplos assustadores: 1- Existem milhões de homens e mulheres desempregados, mas continuamos a obrigar alguns de nós a trabalhar mais de 50 horas por semana ou, ainda pior, a recorrer ao trabalho infantil ; 2- Produzimos cada vez mais, mas, pelo contrário, não produzimos cada vez melhor, apesar dos constantes avanços técnicos e tecnológicos ${ }^{[1]}$. Para além disso, nem mesmo aquilo que produzimos em excesso é distribuído pelas classes desfavorecidas (em particular por aqueles que morrem de fome, literalmente) e isto é algo absolutamente imoral.

O nosso carácter parece estar a ficar profundamente corroído, em parte, por termos perdido a sensação de que somos úteis para os outros e de que temos um papel a desempenhar no seio da comunidade, ou seja, é a nossa própria vivência ancestral coletiva que parece estar a desmoronar-se. A coesão está mais frágil e a conceção de que temos uma função social útil para desempenhar torna-se cada vez menos clara e evidente. Paralelamente, a ideia de contrato social (onde está subjacente a noção de que cada um dos membros da sociedade tem mais vantagens em viver em conjunto do que isoladamente) parece estar a desvanecer-se, devido aos processos de individualização impulsionados pelo atual capitalismo flexível. Estaremos nós a caminhar para aquilo que Hobbes (1983) designou como estado de natureza, em que, neste caso, a fugaz sobrevivência humana só poderia ser obtida através da guerra de um contra todos ? 0 problema é que perante este cenário hipotético não haverá vencedores, todos estaremos inevitavelmente vencidos ! É precisamente por isso que a noção de contrato social (preconizada por Jean-Jacques Rousseau, 1989) é mais vantajosa para todos. Dentro deste contexto, é importante vincar a seguinte ideia: “Um regime que não dá aos seres humanos razões profundas para cuidarem uns dos outros não pode manter por muito tempo a sua legitimidade" (Sennett, 2001, p. 225).

7 Segundo uma assertiva expressão utilizada por diversos autores, desde meados da década de 1970, existe uma dualização do mercado de trabalho, dado que muitas empresas têm gerado, por um lado, uma elite de trabalhadores, com rendimentos consideráveis e relativamente estáveis ao nível da sua situação laboral e, por outro lado, uma esmagadora maioria de trabalhadores precários, mal remunerados e sem qualquer nível de proteção e segurança no emprego ${ }^{[2]}$. Por motivos diferentes, quer uns, quer outros, acabam por estar sujeitos a pressões significativas oriundas do seu ambiente laboral, devido, por exemplo, ao excesso de trabalho e a jornadas bastante mais longas do que seria admissível ${ }^{[3]}$. Após este pequeno enquadramento pouco animador sobre o momento histórico que estamos a viver, volto a sublinhar qual é o verdadeiro objetivo deste texto. Daqui por diante, irei tentar debater quais são os principais efeitos do trabalho na qualidade de vidas das pessoas, particularmente, na sua saúde mental. Esta discussão tem vindo a ganhar importância nos últimos anos e têm chegado muitos contributos de diversas disciplinas científicas; mas a abordagem da psicodinâmica do trabalho (a qual inclui muitos destes achados) destacou-se pela sua originalidade e pertinência. Em resumo, vou socorrer-me da já longa reflexão da escola dejouriana para compreender qual é a verdadeira influência que o mundo do trabalho exerce sobre nós. 


\section{Sobre as noções de trabalho e de saúde}

Acredito que será útil começar por efetuar algumas considerações sucintas acerca da noção de trabalho, dado que é em torno deste tema que gira uma parte significativa da reflexão da psicodinâmica do trabalho. Atualmente a divisão social do trabalho complexificou-se de tal forma que já não se limita a umas quantas operações simples realizadas ao longo da vida, tal como era preconizado por Adam Smith (1979), no seu clássico "A riqueza das nações". Segundo as suas palavras, naquela época a vida dos trabalhadores estava remetida para uma quase inevitável ignorância (visão que, de certo modo, Marx (1993) também perfilhava quando abordou o tema da alienação provocada pelo trabalho). Mesmo depois do contributo de Durkheim (1984), em particular com o seu livro intitulado "A divisão social do trabalho", verificaram-se significativas alterações à forma como o trabalho é compreendido, organizado e executado, nomeadamente após a década de 1980. Aliás, nas últimas décadas o trabalho foi alvo de uma profunda intensificação (Dal Rosso, 2008). Para Dejours (2005) o trabalho traduz-se numa atividade socialmente útil e carece de técnicas para a sua execução (embora, como iremos ver adiante, elas possam ser insuficientes para alcançar as metas ditadas pela coordenação). Esse mesmo trabalho assume, na atualidade, uma enorme variedade de formas, suscita uma grande diversidade de entendimentos e é concebido de maneiras diferentes pelos múltiplos atores/agentes sociais, consoante, por exemplo, a sua localização na estrutura social (Freire, 2002). 0 conceito de trabalho está cheio de controvérsias sendo mesmo, nos dias de hoje, insuscetível de se tornar consensual, tendo em conta as diversificadas correntes que o abordam (Dejours, 1998).

9 Para além disso, é imprescindível não esquecer que a esmagadora maioria da população mundial faz depender a sua subsistência do trabalho, ou seja, são uma enorme classeque-vive-do-trabalho (Antunes, 2008). O conceito de trabalho é polissémico e multifacetado, apesar de poder conter algumas regularidades relativamente à sua organização social. Revela, no entanto, um papel fundamental na construção de identidades (individuais e sociais), é passível de conter resistências e conflitos, depende de afetividades e emoções, está repleto de diferentes formas de poder e dominação e é ainda suscetível de gerar quer coesão e emancipação, quer descompensações e malestar. É, portanto, suficientemente ambivalente, podendo ser compreendido de forma polarizada: entre o prazer que suscita e o sofrimento que produz ${ }^{[4]}$. Dada a sua influência sobre a moral coletiva (entendida como as diferentes formas de convivência social), o trabalho é algo que merece uma permanente reflexão ética. É importante lembrar que o trabalho é algo que não parou de sofrer múltiplas evoluções ao longo dos tempos (ou retrocessos, em determinados casos) e que por isso mesmo carece de uma "constante" reavaliação. Toda a obra de Dejours está centrada na análise e descodificação desta dinâmica do trabalho e na sua influência sobre a saúde mental.

Tentar idealizar um mundo sem trabalho (tal como foi preconizado por alguns autores, os quais profetizavam "o fim do trabalho"), parece cada vez mais um cenário irrealista ou dificilmente sustentável. Entendo que devido à magnitude da sua presença e da sua função na vida dos indivíduos, bem como no funcionamento das sociedades, imaginar um mundo sem trabalho soa a algo absurdo ${ }^{[5]}$. Apesar de as previsões em determinados contextos serem altamente falíveis, penso que o trabalho continuará a acompanhar a história da humanidade (pelo menos nos tempos mais próximos, exceto se ocorrer uma 
alteração tão extraordinariamente inesperada que possa ser designada como um Cisne Negro - no sentido proposto pelo filósofo Nassim Taleb, 2008). Fazendo fé que não ocorrerá esse evento inesperado, manter-se-á a pertinência de tentar aferir quais são os diversos efeitos que o trabalho produz na vida das pessoas, incluindo na sua saúde.

Diversas organizações internacionais (nomeadamente a OMS) definem a saúde como um estado de bem-estar físico, mental e social. Dejours (1986) critica essa definição essencialmente por dois motivos : por um lado, se tentarmos aprofundar o que é esse bem-estar, verificamos que é quase impossível de definir ; por outro lado, esse completo e perfeito estado de bem-estar, não existe. No seu entender, esta noção de bem-estar associada à saúde é muito vaga. A saúde não é um estado permanente, algo que depois de atingido se mantenha estável. Deve ser entendida como um objetivo a ser atingido, como um fim. Por isso, a saúde passa por "ter meios de traçar um caminho pessoal e original, em direção ao bem-estar físico, psíquico e social" (Dejours, 1986 : 11). De certo modo, pode-se afirmar que é através da análise psicodinâmica das vivências singulares e únicas do trabalhador, articuladas com a organização do trabalho, que se estabelece a compreensão do processo saúde/doença no trabalho.

12 Para o autor, existem três elementos que podem ajudar a construir um "novo conceito" de saúde : a fisiologia, a psicossomática e a psicopatologia do trabalho. O primeiro está relacionado com o próprio funcionamento do organismo, ou seja, os preceitos que asseguram o seu equilíbrio e sobrevivência. $O$ segundo elemento traduz-se através da relação entre o que se passa na mente humana e o funcionamento dos seus corpos; há interações permanentes entre corpo e mente. Por último, o terceiro elemento defende que o trabalho pode ser um aspeto fundamental para a saúde. É verdade que o foco da psicopatologia do trabalho está, em grande medida, direcionado para os aspetos negativos do trabalho ; contudo, reconhece que quando a organização do trabalho não colide com as aspirações, com as ideias e com os desejos dos trabalhadores, será justamente um meio de promover a saúde através do trabalho.

\section{A psicodinâmica do trabalho}

A obra de Christophe Dejours oferece uma reflexão singular sobre a influência do trabalho na saúde mental dos sujeitos. Este tema é indiscutivelmente importante na contemporaneidade, dadas as múltiplas consequências (positivas e/ou negativas) que podem provocar nos trabalhadores, bem como na forma como organizamos, dividimos e distribuímos socialmente o trabalho. Numa perspetiva histórica, o autor destaca que a clínica do trabalho e a psicopatologia do trabalho, as quais surgiram em meados do século passado, dedicaram-se, exclusivamente, aos efeitos negativos do trabalho. Entretanto, durante a década de 1980, chegaram novos contributos para esta discussão, oriundos de outras abordagens disciplinares, nomeadamente a ergonomia, a psicologia, a sociologia, a psicanálise, a medicina ou a antropologia (isto só para citar algumas delas). Na década seguinte emerge uma nova disciplina, designada por psicodinâmica do trabalho, onde é ampliado o debate sobre os efeitos do trabalho na saúde mental. A psicodinâmica do trabalho baseia-se na teoria da centralidade do trabalho, a partir de diferentes níveis (Dejours, 2017). Dentro desta renovada conceção, o trabalho deixou de ser apenas observado a partir dos seus fatores negativos, passando também a considerar os aspetos positivos que nos pode proporcionar. Esta dualidade não é exatamente nova, tendo em conta que já desde Karl Marx (1993) sabíamos que o 
trabalho nos podia oferecer o "melhor" e o "pior" para a nossa existência. O trabalho tanto pode auxiliar na emancipação, como conduzir à alienação. Contudo, aquilo que parece constituir-se como algo realmente novo nesta abordagem é a descoberta da extraordinária influência que o trabalho pode ter sobre a saúde mental, destapando o véu sobre a subjetividade ${ }^{[6]}$ inerente à forma como cada trabalhador lida com o próprio ambiente laboral. O trabalhador nunca é um sujeito passivo perante os constrangimentos impostos pela organização do trabalho. É por esse motivo que o trabalho dificilmente pode ser considerado como um elemento neutro perante a saúde mental (Dejours, 1999). Trabalhar não é apenas produzir, é construir-se a si próprio, é transformar-se e criar a sua identidade, por exemplo, via psicodinâmica do reconhecimento. Outro vetor importante debatido pela psicodinâmica do trabalho é a mobilização subjetiva do trabalhador. Este processo traduz-se pelo comprometimento do trabalhador com o seu trabalho fazendo uso da subjetividade, da inteligência prática e do coletivo de trabalho para transformar os fatores da organização do trabalho que são suscetíveis de gerar sofrimento (Dejours, 2005). De certa forma, esta disciplina procura compreender o significado do trabalho para o sujeito. Em resumo, a psicodinâmica do trabalho "se define como a análise psicodinâmica dos processos intersubjetivos mobilizados pela situação do trabalho" (Sznelwar, Uchida \& Lancman, 2011, p. 12). Julgo que estes são alguns dos aspetos inovadores que esta abordagem nos tem vindo a transmitir, a partir de um manancial de conhecimentos, simultaneamente, teóricos e empíricos.

Penso já ter deixado suficientemente explícito que existem sobreposições temáticas entre a psicopatologia do trabalho e a psicodinâmica do trabalho. Enquanto a primeira estava maioritariamente centrada nas doenças mentais provocadas pelo trabalho, a segunda foi além disso e tentou compreender como é que os trabalhadores lidavam com o sofrimento provocado pela violência imposta pela organização do trabalho e, particularmente, quais as estratégias que utilizavam para se proteger/defender desse mesmo sofrimento. Talvez o grande enigma que a psicodinâmica do trabalho pretenda responder seja o seguinte : como é que muitos trabalhadores conseguem manter a sua sanidade mental, numa espécie de homeostasia, quando em determinadas situações podem ser alvo de profundos ataques oriundos do seu ambiente laboral ? É pertinente lembrar que o atual modelo económico - capitalismo flexível - tem corroído o nosso caráter (Sennett, 2001) e as suas políticas neoliberais estão a dar origem a uma verdadeira hecatombe social, onde podemos incluir, por exemplo, diversas assimetrias que estão na base da pobreza e da exclusão, além de promoverem uma competitividade empresarial exacerbada, reestruturações desastrosas, desemprego e precariedade (Bourdieu, 1998; de Gaulejac, 2007; Standing, 2014). Tendo em conta este contexto seria expectável observarmos muitos trabalhadores a entrarem em descompensação, mas, na verdade, verificamos empiricamente que isso nem sempre acontece. Então, torna-se incontornável perguntar o que estará a "salvar" um grande número de trabalhadores destas brutais ofensas provenientes do mundo do trabalho? A resposta da psicodinâmica do trabalho para esta melindrosa questão é a de que os trabalhadores encontraram diferentes estratégias (individuais e/ou coletivas) para se protegerem da violência emanada das formas atuais em que se encontram as relações laborais e a organização do trabalho. Isto significa que muitos trabalhadores encontraram um meio para suportar e ajustar o sofrimento produzido pelo trabalho e, ainda assim, manter a aparente normalidade do seu funcionamento psíquico. $O$ autor empregou o conceito de estratégias defensivas para definir o "escudo protetor" utilizado pelos trabalhadores 
(Dejours, 1991). Para além disso, Dejours (1999, p. 18) refere que as estratégias de defesa construídas por homens e mulheres são, por vezes, subtis, cheias de engenhosidade, diversidade e inventividade.

\begin{abstract}
"Em face do sofrimento, o ego não fica passivo, ele se defende. As pesquisas em psicodinâmica e psicopatologia do trabalho mostram que existem defesas individuais e coletivas contra o sofrimento no trabalho. E essas defesas têm em comum funcionar como atenuadores da consciência desse sofrimento, como uma espécie de analgésico" (Dejours, 2005, p. 60).
\end{abstract}

Contudo, apesar deste mecanismo defensivo ser normalmente bastante eficaz (evitando as referidas descompensações psicopatológicas), é importante sublinhar que a utilização deste tipo armaduras também revela o seu lado contraproducente. Na verdade, as estratégias defensivas podem funcionar como uma armadilha que insensibiliza os trabalhadores contra aquilo que os faz sofrer (Dejours, 1999). Isto é, servem para tolerar o intolerável. Não apenas para consigo, mas também para com o sofrimento dos outros. Um dos seus maiores perigos que esta situação acarreta é tornar suportável o "sofrimento ético"; isto acontece quando o trabalhador é obrigado a praticar determinadas ações que condena moralmente, por causa do seu trabalho. Este efeito de reprovação da consciência moral (ou de afronta aos valores sociais) pode ser denominada como traição do Ego, pelos psicanalistas, ou como dissonância cognitiva, pelos psicólogos.

16 A noção de coletivo de trabalho está no âmago da abordagem da psicodinâmica do trabalho. Esta disciplina aduz que pensar num coletivo implica a presença de um grupo ou de uma comunidade estruturada por regras, por códigos de conduta que decorrem de compromissos e pactos dentro do coletivo de trabalho. É através da estabilização das regras dentro do grupo que os sujeitos conseguem trabalhar juntos e construir um coletivo de trabalho. Existem as regras que provêm do trabalho prescrito, as quais têm de ser complementadas pelas "regras" que emergem do real do trabalho, as regras informais, as experiências e os saberes práticos dos trabalhadores. Porém, as atuais técnicas de gestão estão a desestruturar os coletivos de trabalho (de Gaulejac, 2007), ou seja, há uma intensa degradação do viver-junto em coletividade e isso, em situações extremas pode estar na base de suicídios relacionados ao trabalho (Dejours \& Bègue, 2009).

17 Se o trabalho real funciona bem são produzidos consensos no coletivo de trabalho. 0 somatório desses consensos transforma-se em "novas regras de trabalho". A coesão dos coletivos de trabalho - que se constrói a partir da confiança recíproca - demonstra que os trabalhadores conhecem as regras, que cooperam entre si, mas também que as conseguem contornar e ludibriar. Porque não há regras universais que funcionem em todos os contextos, situações e circunstâncias. Há sempre as exceções e os imprevistos que necessitam de ser enfrentados pela inteligência, criatividade e inventividade dos trabalhadores. Por outras palavras, precisam de utilizar o trabalho vivo (Dejours, 2012). A coordenação que advém do trabalho prescrito necessita de ajustes efetuados pelo trabalho realizado (Dejours \& Gernet, 2011). Mas, quando um coletivo chega a uma interpretação compartilhada, comum ao coletivo, forma-se uma cooperação. Coordenação e cooperação são os dois termos ao nível coletivo que representam o desfasamento entre tarefa e atividade ao nível individual (Dejours, 2016, p. 324). 


\section{Trabalho prescrito e trabalho real} quando estamos a trabalhar. Tal como refere Dejours, trabalhar é correr riscos e isso implica ter de gerir a alguma incerteza. Normalmente o trabalho prescrito não considera as limitações da própria condição humana [8], logo, torna-se um fator potenciador de lapsos, erros, falhas e acidentes. Para além disso, as situações de trabalho são, em larga medida, fixadas de modo independente da vontade do sujeito, são moduladas por decisões dos outros (Molinier, 2006) e isso vai gerar constrangimentos na sua forma de agir. 0 trabalho prescrito é a forma como a entidade empregadora concebe e organiza o modo de realização do trabalho (tarefas a executar, tempos de trabalho, regras, normas, procedimentos, recursos materiais e humanos para cada função, tipo de máquinas utilizado, etc.) ; no fundo, é projetar como é que o trabalho deve ser feito. No entanto, o design do trabalho, por melhor elaborado que esteja, nunca consegue prever todas as circunstâncias, constrangimentos, dificuldades e obstáculos que a sua realização prática pode implicar. Até ao fim de vários anos de laboração podem sempre surgir coisas novas e inesperadas. Nem mesmo as organizações que trabalham em cenários de alto risco e que regra geral apostam bastante na segurança - nesse contexto está subjacente a ideia de mindfulness conseguem antecipar e detetar todas as situações suscetíveis de causar danos (Areosa, 2012b). Isto significa que os executantes do trabalho prescrito nunca conseguem cumprir na íntegra o modelo que foi desenhado pela organização, mesmo que o quisessem fazer (recorrendo àquilo que Dejours designa metaforicamente por greve de zelo). Existem várias causas e explicações para isso, as quais têm normalmente como pano de fundo o fato de o trabalho ser, regra geral, uma entidade dotada de imprevistos.

o trabalho real é sempre muito mais rico e diversificado do que aquilo que os organizadores/mentores do trabalho prescrito conseguem prever. Porém, é importante lembrar que o trabalho prescrito resultou sempre do trabalho real de alguém (Clot, 1995). No mundo do trabalho há sempre incertezas, resistências, dificuldades, obstáculos, incidentes ou acidentes. Por isso, é pertinente referir que trabalhar implica normalmente efetuar adaptações, fazer ajustes ou criar alternativas para, por exemplo, ultrapassar as dificuldades impostas por novas situações. Algumas vezes isso também implica não cumprir regras ou tentar contorná-las para que a execução do trabalho seja possível. Não é tanto uma resistência à autoridade hierárquica, é essencialmente para tentar "fazer bem as coisas". Nenhuma organização pode funcionar adequadamente sem que os seus trabalhadores utilizem este tipo de estratégias, pois a execução estrita

Laboreal, Volume 15 N$^{\circ} 2$ | 2019 
das prescrições oficiais (ou seja, fazer greve de zelo) é condenar uma organização ao fracasso e ao insucesso. A título de exemplo, Dejours refere o seguinte: "Se os enfermeiros executassem rigorosamente as ordens dos médicos, haveria muitos mortos nos hospitais, o que precisamente conseguem evitar graças ao seu zelo" (Dejours, 2013, p. 11).

21 Os desvios ao trabalho prescrito não são apenas uma forma de desobediência ao controlo hierárquico, são acima de tudo - volto a frisar - uma necessidade imperativa para conseguir realizar o trabalho de forma eficiente. Mas há outras dificuldades colocadas aos trabalhadores durante a execução das suas atividades. Dejours (2005, p. 40) define o real como aquilo que no mundo se faz conhecer pela sua resistência ao domínio técnico e ao conhecimento científico. O real implica uma certa descoberta. No seu entender, os termos "trabalho real" e "real do trabalho" não são sinónimos. Remetem-nos para referenciais teóricos distintos. Sem aprofundar este aspeto, creio que vale a pena sublinhar o que se entende por real do trabalho: diante da tarefa é inevitável que a falha humana possa ocorrer, já que o real só se apreende sob a forma de revés. $O$ real do trabalho revela os limites do saber e do conhecimento ; revela ainda os obstáculos da atividade, os quais colidem com os atos técnicos, por vezes, colocandoos em xeque (Dejours, 2005). Paralelamente, a utilização do zelo por parte dos trabalhadores permite recriar o trabalho e encontrar soluções para as dificuldades não previstas pelos mentores da organização do trabalho. Por vezes isso implica ter de transgredir ordens ou instruções formais. Ao trabalho prescrito é acrescentada a inteligência dos trabalhadores para que as coisas funcionem. A aplicação desta inteligência é designada por trabalho vivo, o qual se torna imprescindível para o normal funcionamento de qualquer organização (Dejours, 2012). Não há nenhuma organização que possa prescindir do trabalho vivo, dado que o prescrito é sempre incompleto. Contudo, a partir deste ponto de vista, o trabalho vivo é, regra geral, um enigma, visto que não sabemos antecipadamente o que será necessário fazer para que funcione. É preciso recorrer à criatividade, empenho, esforço e sensibilidade dos trabalhadores. Mas o trabalho vivo é simultaneamente suscetível de gerar medo, devido a colocar o trabalhador perante o cenário de enfrentar um possível fracasso. Paralelamente, o modelo de organização social baseado no capitalismo tem acentuado a transformação do trabalho vivo em trabalho morto (Antunes, 2008).

Em resumo, o que será então necessário acrescentar às prescrições formais (regras, normas, procedimentos, instruções de trabalho, ordens, etc.) para que funcionem de forma eficaz? Segundo Christophe Dejours (2013) a resposta para esta questão encontra-se nas múltiplas formas de zelo que os trabalhadores utilizam para desempenhar bem a sua função (num sentido similar, em português, existe a expressão brio profissional). De certo modo, pode-se afirmar que o trabalho vivo não é mais do que as diversas fornas de zelo aplicadas pelos trabalhadores. Por outras palavras, o zelo é aquilo que o sujeito acrescenta às prescrições para atingir os objetivos do trabalho. 0 zelo permite assim gerar soluções que reduzam o afastamento entre o trabalho prescrito e o trabalho real.

Pretendo ainda voltar aos motivos que estão por trás dos "desvios" efetuados pelos trabalhadores. A sua ocorrência não significa que eles sejam na sua maioria imputáveis à vontade, autonomia ou liberdade de decisão dos próprios trabalhadores; pelo contrário, a forma como está planeada a execução do trabalho pode estar subjugada por múltiplas questões organizacionais (impossibilidade técnica para executar certas 
tarefas, avarias em máquinas ou equipamentos cujo bom senso aconselharia a sua paragem, mas que continuam a funcionar sem estar garantida a segurança, pressão para aumentar a produção e por aí adiante) ; é também isto que pode implicar desvios ao trabalho prescrito.

Existem ainda outros tipos de desvios que estão relacionados com a própria condição humana, particularmente com o nosso funcionamento cognitivo. Estou a falar de algo que nos é intrínseco, onde se incluem todas as potencialidades e limites relacionados com a nossa forma de pensar. O psicólogo Daniel Kahneman (2012) e o neurocientista António Damásio (1994) têm produzido conhecimentos extraordinários neste campo, embora numa ótica bastante diferente daquela que é utilizada na psicodinâmica do trabalho. Anteriormente George Miller (1956) já tinha defendido que a nossa espécie só tem capacidade para processar uma certa quantidade limitada de informação de cada vez. Quando esse limite é ultrapassado, ficamos sobrecarregados e o nosso rendimento começa a baixar drasticamente. Talvez seja por isto que só conseguimos dar atenção e cumprir um número restrito de normas, regras, procedimentos ou tarefas e tendemos a ignorar outras ${ }^{[9]}$. Contudo, verifica-se que algumas organizações continuam a não considerar a importância da interação entre os fatores humanos (ao nível biopsicossocial) e as componentes técnicas e tecnológicas incorporadas na organização do trabalho (Areosa, 2012a).

Dentro deste contexto, pretendo ainda abordar a perspetiva de Amalberti (1996), onde o autor desenvolve um modelo denominado gestão cognitiva dinâmica ou compromisso cognitivo. Segundo o seu ponto de vista, os trabalhadores gerem permanentemente a sua atividade laboral através de um compromisso cognitivo entre riscos internos e riscos externos. Os primeiros são aqueles que os trabalhadores aceitam sujeitar-se, enquanto os segundos estão relacionados com os diferentes ambientes de trabalho, onde se encontram várias categorias de risco, nomeadamente, riscos físicos, químicos, biológicos, psicossociais, etc. (cf. Areosa, 2011 ; 2014). Quando Amalberti defende que nem todos os desvios ao trabalho prescrito são necessariamente negativos, esta ideia está a considerar de modo muito consistente alguns dos conhecimentos sobre a nossa forma de pensar quando estamos a trabalhar. No decorrer das suas atividades laborais alguns trabalhadores preferem efetuar "desvios" ao trabalho prescrito, quando sabem antecipadamente que esses "erros" não se traduzem em cenários ou consequências perigosas para a organização (ou para si próprios), do que ter de cumpri-lo à risca e ter basear o seu funcionamento cognitivo em regras que tornam o trabalho mais lento, desgastante, fastidioso e que envolve recursos fatigantes. Aceitar determinados desvios considerados inconsequentes pode revelar-se uma gestão mais económica do ponto de vista cognitivo (Amalberti, 1996). Afinal, parece que o nosso cérebro não está programado, numa perspetiva evolutiva, para desperdiçar energias e recursos desnecessariamente.

Segundo Rasmussen (1997) a análise do trabalho real vem muitas vezes demonstrar uma variedade de situações vividas pelos trabalhadores que não vêm previstas nas normas e regras (de segurança) das empresas. A gestão desta variabilidade nos diversos locais de trabalho carece de "adaptações locais". A título de exemplo, refiro que já pude observar numa investigação realizada em contexto hospitalar que as regras informais dominam largamente o quotidiano deste tipo de organizações (Areosa \& Carapinheiro, 2008 ; Areosa, 2011). No setor dos transportes ferroviários a realidade é similar àquela que encontrei no ambiente hospitalar (Areosa, 2012a). Neste último estudo, alguns 
trabalhadores "da linha da frente" afirmaram que determinadas normas, regras ou procedimentos parecem ser elaboradas estritamente "em gabinete", por alguém que não conhece a realidade prática e quotidiana da organização, pois essas prescrições laborais só funcionam em teoria, mas não na prática. Em casos extremos como este, é óbvio que esta condição prejudica bastante a realização de algumas tarefas, dado que as instruções normativas estão desfasadas da realidade.

Tal como muitos outros autores, Sidney Dekker (2006) também corrobora as legítimas preocupações que distinguem o trabalho prescrito do trabalho real. A visão distorcida que, por vezes, a gestão de topo revela sobre a forma como imaginam que o trabalho é feito e como ele é efetivamente realizado pode tornar as organizações mais frágeis e, por consequência, menos resilientes. As organizações de alto risco são particularmente vulneráveis perante este tipo de condicionalismos (Areosa, 2012b). Um dos muitos problemas que provoca a descoincidência entre o trabalho prescrito (idealizado) e o trabalho real (aquele que é realizado na prática) decorre de não se analisar se as normas prescritas são, de facto, exequíveis ou aplicáveis para realização das tarefas pretendidas ou se existem, por exemplo, outros aspetos de natureza cognitiva suscetíveis ter causado algum tipo de "armadilha" (Amalberti, 1996) e que podem estar na base daquilo que alguns analistas menos experientes (ou ideologicamente contaminados) consideram o grande problema da segurança organizacional, o designado erro humano. Os trabalhos do psicólogo James Reason (1990) e do sociólogo organizacional Charles Perrow (1999) são referências indiscutíveis no debate desta matéria.

\section{Atividade deôntica e reconhecimento}

Dejours (2013) defende que a construção e reconstrução de regras consomem uma parte significativa do nosso tempo e energia ; esta condição é apelidada de atividade deôntica. As regras no trabalho nunca são apenas técnicas, são também sociais, pois implicam convivência. Normalmente o trabalho envolve uma relação com o outro, não é apenas produzir, é, sobretudo, um jogo de experiências em conjunto com o outro. Os trabalhadores que se recusam a fazer greve de zelo, aqueles que são pró-ativos na cooperação com a organização do trabalho, esperam que esta atitude possa ser compensada. Anseiam que o seu contributo tenha uma retribuição ; não somente uma recompensa material - indiscutivelmente importante, mas não a mais importante segundo as palavras de Dejours - acima de tudo esperam uma retribuição simbólica, cujo expoente máximo é o reconhecimento.

O poder simbólico que é exercido pelo reconhecimento resulta, em parte, da mobilização subjetiva dos trabalhadores e do julgamento dos outros. Neste contexto, existem dois tipos de julgamentos no trabalho: 1) aquele que é efetuado pelas hierarquias, a partir de uma perspetiva mais utilitarista (utilidade técnica, económica ou social) ; e 2) aquele que é preconizado pelos pares (é aqui que reside a beleza do trabalho). Este segundo tipo de julgamento diz respeito à conformidade do trabalho, da produção ou do serviço, ou seja, está relacionado com as "artes do ofício" (Dejours, 2005). É pertinente referir que de reconhecimento em reconhecimento o trabalhador vai fortalecendo a sua identidade, a sua saúde e o seu bem-estar no trabalho, evitando deste modo uma maior vulnerabilidade aos riscos psicossociais do seu trabalho (Facas et al., 2015). 0 reconhecimento desempenha um papel crucial relativamente à prevenção do 
sofrimento patogénico, dado que confere significado aos esforços exercidos por cada trabalhador (Rolo, 2018), atribuindo dignidade ao próprio ato de trabalhar (Wandelli, 2015).

$\mathrm{O}$ ato de trabalhar está relacionado com a forma de mobilizar o corpo e com a utilização da inteligência do trabalhador, no sentido de produzir algo que incorpore valor (Dejours, 1998). Destaco que o trabalho está profundamente relacionado com a realização do ego e que o fortalecimento da nossa identidade se constitui, em parte, como uma armadura da nossa saúde mental. 0 reconhecimento assume neste processo um papel extraordinário, dado que quando não há reconhecimento o mais provável é que o trabalho se resuma a uma expressão de sofrimento. A falta de reconhecimento no trabalho é suscetível de gerar um círculo vicioso de sofrimento, desestabilizador da identidade e tudo isto pode conduzir à doença mental.

\footnotetext{
"Quando a qualidade de meu trabalho é reconhecida, também meus esforços, minhas angústias, minhas dúvidas, minhas decepções, meus desânimos adquirem sentido. Todo esse sofrimento, portanto, não foi em vão; não somente prestou uma contribuição à organização do trabalho, mas também fez de mim, em compensação, um sujeito diferente daquele que eu era antes do reconhecimento. $O$ reconhecimento do trabalho, ou mesmo da obra, pode depois ser reconduzido pelo sujeito ao plano da construção da identidade. E isso se traduz afetivamente por um sentimento de alívio, de prazer, às vezes de leveza d'alma ou até de elevação" (Dejours, 1999, p. 34).
}

31 Neste contexto é imprescindível não esquecer qual é o sentido que o trabalho assume na contemporaneidade. $O$ trabalho de cada um deveria estar ao serviço da comunidade, mas o capitalismo tem provocado a implosão do mundo do trabalho e a consequente falência de um universo social coerente. O capitalismo flexível tem originado uma profunda desestabilização dos empregos estáveis e, para muitos trabalhadores, uma intermitência entre trabalho precário e desemprego. Além de todas as consequências materiais que o desemprego acarreta, ele gera medo, ansiedade, porque faz pairar sobre nós o fantasma da inutilidade (Sennett, 2006) e isso é absolutamente aterrador para a saúde mental. Talvez o maior desafio que o capitalismo flexível nos coloque seja o de saber "quem precisa de nós" ? Esta pergunta está longe de ter uma resposta imediata, mas se não houver o reconhecimento de que o nosso trabalho é importante, de que exercemos uma função social útil, o nosso ego sente-se perdido no universo social, bem como nós próprios enquanto seres sociais; e as pessoas sentem falta de maior coesão social, de relações humanas sustentadas e de objetivos duradouros (Sennett, 2001, p. 153).

32 Termino a discussão desse aspeto reforçando a ideia de que o reconhecimento serve para transformar o sofrimento resultante do trabalho, em prazer, em consolidação do ego e em fortalecimento da identidade. Quando Dejours (2013) debate esta questão entra profundamente no domínio psicanalítico, onde se aborda o conceito de sublimação , o qual tem sido alvo de inúmeros contributos por parte da psicodinâmica do trabalho.

\section{Os novos métodos da organização do trabalho: mecanismos de controlo e repressão}

As novas formas de gestão das organizações, impostas pela cúpula hierárquica, acabam por fomentar a diluição dos elos sociais, da coesão e da interajuda entre pares. Este 
fenómeno que começou a emergir a partir da década de 1980 é suficientemente perverso para a identidade e integridade dos trabalhadores, dado que quebra as suas redes de solidariedade, incorporando o medo e a solidão no mundo do trabalho (Dejours, 2011). O nosso quotidiano está, aparentemente, dominado pelo enfraquecimento de alguns vínculos sociais ancestrais. Uma das muitas formas para compreender a atual desestruturação socio-organizacional já foi anteriormente designada por desintegração do grupo de trabalho (Areosa \& Dwyer, 2010), a qual pode ser efetuada, por exemplo, através de políticas de outsourcing, dado que estas estratégias utilizadas no orbe capitalista tendem a promover a precarização do trabalho e uma elevada rotatividade de trabalhadores nas empresas (Sennett, 2001).

Tudo isto tem como consequência imediata uma maior vulnerabilidade dos trabalhadores "da linha da frente" às patologias do foro mental, as quais podem ter custos e consequências muito elevados. A título ilustrativo, os dramáticos suicídios em algumas organizações francesas (extensíveis a outras realidades do mundo ocidental) parecem ter-se tornado virais (utilizo este termo no sentido de contagioso, algo que se tornou numa espécie de mini-epidemia). Na base desta sequência de suicídios esteve, entre outras situações, o silêncio, a covardia e o abandono por parte dos colegas de trabalho (Dejours \& Bègue, 2009). Esta conduta parece ter como explicação as alteraçães na organização do trabalho e as consequentes perdas de solidariedade entre pares. Isto não significa, obrigatoriamente, que o sofrimento seja maior hoje do que foi no passado, significa antes que as nossas resistências se tornaram menos eficazes. E porquê? Porque estamos cada vez mais isolados nos nossos locais de trabalho. Deste ponto de vista, poderei afirmar que a psicodinâmica do trabalho revela uma preocupação mais humanista, por comparação com outras disciplinas, particularmente a gestão. Existem inúmeros indícios sobre os efeitos iatrogénicos dos "novos" modelos de gestão. Atualmente a gestão é uma tecnologia de poder, colocada ao serviço do capital, cuja finalidade é adaptar os trabalhadores, de múltiplas formas, às exigências das empresas (de Gaulejac, 2007). Este poder tem como função tornar os corpos "úteis, dóceis e produtivos". O poder do capital é mantido, por exemplo, através da "patologia da indiferença" para com o outro (Mendes, 2018). Embora a gestão em si mesma possa não ser obrigatoriamente um mal, neste momento a forma como está a ser utilizada (ao serviço do capital) coloca as sociedades e o mundo do trabalho sob enorme pressão. $\mathrm{E}$ isso afeta a saúde mental! Para a gestão a "otimização constante" (melhoria continua) é um dogma e a "qualidade total" é uma bíblia. A lógica subjacente é fazer sempre mais, mais barato, mais rápido, melhor, com os mesmos meios e com menos trabalhadores. A degradação dos coletivos de trabalho e a individualização dos trabalhadores contribui para "psicologizar" as causas do sofrimento, as quais resultam, na verdade, da pressão exercida pela gestão (de Gaulejac, 2007).

Pretendo ainda abordar algumas questões relativas aos novos métodos da organização do trabalho, bem como as suas implicações para a saúde dos trabalhadores. Já foi referido que dentro das organizações o trabalho depende de dois fatores chave: a coordenação (a qual implica o uso de poder sobre os outros, enquanto forma de dominação) e a cooperação (onde está implícita uma certa forma de convivialidade). Segundo a perspetiva de Dejours (opinião expressa numa entrevista ao jornal Público, em 1 de Fevereiro de 2010) [10], a organização do trabalho sofreu nos últimos anos profundas alterações a partir de três grandes vetores : 1) Emergência de novos métodos de gestão, particularmente a avaliação de desempenho (ao nível individual); 2) 
Introdução de técnicas ligadas à designada "qualidade total" (sistemas de certificação, círculos de qualidade, protocolos de atuação, etc.); e 3) Políticas de outsourcing (que conduzem à precarização no emprego).

Num estudo sobre trabalhadores de call center, foi utilizada a expressão "o reino da performance" para definir aquele tipo de organizações, cujas exigências são levadas ao extremo (Dejours, 2015). A avaliação das performances individuais dentro das organizações tem como propósito principal medir "objetivamente" o desempenho dos trabalhadores, de forma quantitativa e comparativa. Dejours (2013) afirma taxativamente que este método é cientificamente incorreto. Na verdade, dificilmente se pode medir o trabalho em si mesmo, aquilo que se pode medir são os resultados do trabalho. Todavia, o trabalho realizado e os resultados do trabalho são coisas muitas vezes distintas. Na prática não se consegue medir o tempo que os trabalhadores levam a formar as suas competências (técnicas e/ou relacionais), os saberes e habilidades que necessitam aprender, ou mesmo o tempo psíquico e intelectual que cada um dedica para conseguir realizar as suas atividades (incluindo o tempo de descanso que passam a pensar no trabalho, por vezes roubando horas de sono quando já estão na cama). Para além disso, os resultados do trabalho dependem de diversas circunstâncias (maioritariamente exteriores ao trabalho) que podem ter uma fraca correlação com o esforço e empenho desenvolvidos pelo trabalhador. A sorte está longe de ser um fator despiciente nas nossas vidas, incluindo a vida profissional.

É pertinente referir que a relação do trabalhador com a sua hierarquia (avaliador) está normalmente longe de ser isenta. Regra geral, as relações sociais (abrangendo também as de trabalho) são profundamente dominadas por interesses diversos, por empatias e simpatias pessoais, por imposições ou, pelo contrário, por escolhas livres, por estratégias coincidentes ou descoincidentes entre os sujeitos envolvidos (isto só para referir alguns exemplos), logo, não são neutras, isentas ou justas como inicialmente pressupõem os modelos de avaliação de desempenho. A partir deste ponto de vista a alegada "justiça" dos modelos de avaliação individual são em determinados casos uma fraude e potenciadoras de inúmeras situações de conflito, como se observou, por exemplo, numa empresa do setor ferroviário (Areosa, 2012a). Mas a relação entre hierarquias e subordinados pode estar na origem de casos bem mais dramáticos para a saúde dos trabalhadores. Uma reveladora pesquisa sueca que monitorizou a saúde de mais de 3000 trabalhadores do género masculino, durante cerca de dez anos, com idades compreendidas entre os 19 e os 70 anos, sugere que os "maus chefes" (incompetentes, autoritários ou autocráticos) aumentam significativamente o número de problemas cardíacos nos trabalhadores, incluindo casos fatais (Nyberg et al., 2009). 0 estudo demonstrou ainda que este efeito é cumulativo, ou seja, quanto mais tempo estiverem os trabalhadores sob a alçada deste tipo de hierarquias, maior é o risco de adoecerem. Isto significa que um mau chefe pode matar, literalmente !

Christophe Dejours preconiza que o mundo do trabalho se transformou, em parte, numa guerrilha que faz cada vez mais vítimas ; não porque este "combate" entre pares seja exatamente novo, mas porque a solidão a que cada um ficou remetido afetou profundamente a saúde mental. A génese desta espiral catastrófica para a saúde do trabalhador está em grande medida dependente das atuais formas de organização do trabalho, onde se inclui os modelos de avaliação de desempenho. Não posso deixar de citar um pequeno excerto do texto de Dejours, onde são referidas as consequências deste tipo de práticas : 
"Efetivamente, a avaliação individualizada e quantitativa do desempenho coloca todos os assalariados em concorrência uns com os outros. Os sucessos de um colega tornam-se uma ameaça para o outro assalariado. É agora cada um por si e todos os golpes são permitidos. A desconfiança e o medo recaem sobre o mundo do trabalho. A deslealdade torna-se banal. A amabilidade e a entreajuda desaparecem. As pessoas já não se falam. A solidariedade desaparece. No fim, cada um se encontra só no meio da multidão, num ambiente humano e social repleto de hostilidade. A solidão abate-se sobre o mundo do trabalho e isso muda radicalmente os dados no que diz respeito à relação subjetiva com o trabalho e à saúde mental" (Dejours, 2013, p. 21).

39 Na sequência da avaliação individual de desempenho surge um segundo vetor associado à organização do trabalho, o qual é designado por "qualidade total". Esta é uma outra forma de controlo e avaliação do trabalho em que os gestores traçam como objetivo a "qualidade total". Porém, a "qualidade total" é algo carregado de utopia (similar aos "zero-defeitos" ou aos "zero-acidentes") ; é um mito, é algo idealizado (mas inexistente ou impraticável no mundo real). Pode ser importante ter um ideal de "qualidade total" se este aspeto servir de referencial, se apontar um caminho ou direção, desde que acompanhado por um entendimento absolutamente claro de que não é possível atingilo em pleno. De certo modo, aquilo que se torna assustador nesta questão é que os gestores nem sempre conhecem verdadeiramente as especificidades de cada profissão, mas são eles que vão definir os critérios de avaliação e do controlo da qualidade. Isso acaba por gerar diversos problemas. Dejours afirma que a "qualidade total" é um contrassenso, pois a própria realidade constantemente nos mostra que o mundo real não funciona de forma ideal (por exemplo, o trabalho prescrito é algo que está distante do trabalho real e é por isso que o trabalho vivo se torna imprescindível). Afinal o mundo é um local repleto de riscos, onde predominam as incertezas, as aleatoriedades, as indeterminações, as contingências, os imprevistos, os imponderáveis ou as nãolinearidades (Areosa, 2010), mas parece que agimos sem ter consciência disso.

Nos dias de hoje, podemos observar que muitas empresas entraram na "loucura" da estandardização dos seus processos para obter determinadas certificações (em que normalmente acaba por estar subjacente a ideia de "qualidade total", "zero-defeitos" ou "zero-acidentes"). Veem isso como a "salvação" para os seus problemas externos (pois supõem que isso lhes permite aumentar a credibilidade e o prestígio) e internos; neste último caso, imaginam que as certificações servem para controlar o grande vilão existente dentro das organizações : as falhas humanas (Areosa, 2017). Contudo, estas certificações são muitas vezes uma ilusão fraudulenta e, ainda pior, acarretam diversos problemas que em certos casos as tornam desastrosas. Isto acontece porque quando o ideal de "qualidade total" se torna na condição obrigatória para obter a referida certificação, as falhas passam a ser escondidas ou omitidas e o funcionamento da organização transforma-se numa "dissimulação consentida". As pessoas passam a ter pudor em falar das dificuldades do seu trabalho real (porque a idealização do trabalho prescrito raramente as consegue antecipar) e porque se torna "politicamente incorreto" abordar o que não funciona bem ou o que correu mal, tal como incidentes, erros ou lapsos. Imaginem o quão arriscado se torna os trabalhadores sentirem medo, receio ou ansiedade em reportar falhas ou incidentes em organizações de alto risco. Na verdade, este tipo de inibições pode transformar-se em algo fatal ou catastrófico.

41 Ao nível da saúde mental, a "qualidade total" pode também implicar diversos problemas. E porquê ? Porque em certos casos nos obriga a vivenciar a traumática 
experiência de realizar o nosso trabalho de forma que nos envergonha. Estar fortemente condicionado a fazer batota, a ter de mentir ou a omitir pode transformarse num meio atroz de sofrimento ético. Nos trabalhadores mais zelosos isso tem um efeito (negativo) poderoso sobre a sua saúde mental. o sofrimento ético acontece quando o trabalhador é obrigado a praticar determinadas ações que condena moralmente, por causa do seu trabalho. É uma espécie de traição de si mesmo ou traição do ego. Nas palavras de Dejours :

\begin{abstract}
"O novo capítulo do sofrimento ético torna mais compreensível uma segunda faceta da forma como "a nossa escala social de valores entra em linha de conta », a saber, o julgamento que o sujeito faz de si próprio, não só sobre a qualidade da sua contribuição no que concerne à produção, mas sobre o valor ético da sua prestação. Porque, pela sua atividade de produção, o trabalhador compromete, de facto, o destino de outro, em particular do cliente que tem obrigação de enganar ou do subordinado que deve " colocar sob pressão ". Isto significa que o trabalho não se reduz a uma atividade, implica dimensões que advém da ação, no sentido que Aristóteles dá ao conceito de praxis : ação moralmente justa" (Dejours, 2013, p. 23).
\end{abstract}

Em diversas profissões, nomeadamente a medicina, existem múltiplos protocolos que devem ser seguidos rigorosamente (caso contrário, podem existir fortes penalizações). Mas, por vezes, verifica-se que o protocolo não está em consonância com a avaliação pericial do profissional (dado que as generalizações nunca conseguem compreender e incluir todas as especificidades associadas aos casos particulares); mas o médico sente medo em violá-lo, porque no caso de as coisas "darem para o torto" poderá ser acusado de negligência, porque não fez o que deveria fazer. Caso o profissional opte por seguir o protocolo em detrimento daquilo que a sua experiência pessoal lhe indica que seria adequado fazer, além do sofrimento ético que isso lhe pode custar (e isso já é suficientemente penoso), também estamos perante uma profunda limitação da sua autonomia profissional, imposta pelo ideal de "qualidade total" (Areosa, 2018b). Obviamente que a "qualidade total" oferece algumas vantagens, mas se tivermos em conta aquilo que referi anteriormente, verifica-se que em certos contextos ela torna-se perigosa e contraproducente.

terceiro e último aspeto referido por Dejours está relacionado com as políticas de outsourcing. Contudo, esta questão tem um outro problema a montante : os processos de reestruturação/reengenharia das organizações, os quais se traduzem muitas vezes pela redução do número de trabalhadores (downsizing dos empregos). Segundo Sennett (2001) o downsizing acaba por estar intimamente relacionado com a crescente desigualdade no mundo do trabalho contemporâneo. Considerando que, por exemplo, apenas uma residual minoria de trabalhadores despedidos consegue encontrar um novo emprego auferindo um salário igual ou superior àquele que tinha anteriormente (Sennett cita, por exemplo, o caso dos trabalhadores norte-americanos de meia idade). Mesmo para as empresas os processos de reengenharia tendem a ser altamente enganadores e penalizadores; ou seja, as reestruturações normalmente falham, pois tornam as organizações disfuncionais (em grande parte devido aos processos de redução de pessoal).

Richard Sennett (2001, p.78) refere diversos estudos que apontam resultados desastrosos para as empresas, pois indicam que os processos de reengenharia e consequente downsizing diminuem os lucros e a produtividade das empresas, tendem a não reduzir as despesas e são escassas aquelas que conseguem aumentar a 
rentabilidade. Em resumo, estes processos são normalmente um fracasso, entre outras coisas, porque a moral e a motivação dos trabalhadores caem a pique perante cenários desta natureza. Nem mesmo os trabalhadores "sobreviventes" aos processos de downsizing conseguem alegrar-se, regra geral sucede o inverso ; porque além de verem os seus pares partirem (desintegrando-se o seu coletivo de trabalho), instala-se o medo de serem eles próprios as vítimas seguintes no próximo processo de reengenharia.

Muitos gestores ainda acreditam que o recurso à terceirização [11] (outsourcing ou subcontratação) de determinadas tarefas ou serviços será a chave para reduzir os custos e melhorar a funcionalidade da organização. Também aqui estamos perante uma gritante ilusão, baseada numa crença infundada ! O recurso ao outsourcing é conhecido no jargão dos gestores como dessedimentação organizacional (Sennett, 2006). Este tipo de práticas caracteriza-se por a atribuir determinadas funções a terceiros, libertando a organização de certas "camadas" consideradas secundárias. Com a flexibilização organizacional as empresas engordam ou emagrecem (em termos de número de trabalhadores), mediante a transição de uma tarefa para outra. Muitos empregos permanentes transformam-se em sazonais. Porém, é importante lembrar que a boa relação entre pares é normalmente construída a partir da confiança, a qual é cimentada, por vezes, ao longo de vários anos. Já referi que as estratégias informais - as quais implicam relações de confiança - dominam largamente o funcionamento interno de algumas organizações. Mas quando as pessoas não se conhecem, porque por exemplo trabalham em empresas diferentes, é mais difícil construir relações de confiança e criar redes de solidariedade no trabalho. A integração ou coesão dos grupos de trabalho entre trabalhadores de empresas diferentes tende a ser bastante mais fragilizada.

Numa conversa recente, um trabalhador contou-me um episódio que se tinha passado com ele, o qual é revelador da "distância" que existe entre trabalhadores que partilham o mesmo espaço de trabalho, mas que simultaneamente pertencem a organizações distintas. Apesar de este ser um exemplo bastante comezinho, ilustra plenamente a ideia anterior. Resumidamente, a história foi a seguinte : algures numa estação de metro na cidade de Lisboa, durante o período noturno em que as instalações já estão encerradas ao público, o trabalhador acima referido (pertencente aos quadros permanentes da empresa do ramo ferroviário) solicita a um trabalhador de uma empresa prestadora de serviços de limpeza (em regime de outsourcing) para the emprestar a chave das instalações sanitárias (as quais naquele momento se encontravam fechadas). Surpreendentemente, em vez de emprestar a chave (que estava na sua posse, o que seria naturalmente óbvio por vários motivos), o trabalhador da empresa prestadora de serviços refere que o primeiro trabalhador se deve dirigir três estações adiante, pois seria aí que as instalações sanitárias estariam abertas. 0 leitor repare bem : três estações adiante (tendo em conta que o metro está encerrado, devido ao período normal de encerramento noturno). Cumprir esta indicação implicaria uma deslocação de carro, com a consequente perda de tempo (além da aflição biológica à qual o primeiro trabalhador teria de sujeitar-se), tudo isto sem qualquer justificação plausível. Nunca tinha havido nenhum conflito anterior entre estes trabalhadores, apenas não havia sido construída uma estrutura de solidariedade e confiança entre eles. Não há empatia ${ }^{[12]}$, nem o reconhecimento de que o outro faz parte da sua "equipa de trabalho". Sem entrar em mais detalhes relativos a este caricato episódio, podemos referir que as políticas de outsourcing são passíveis de originar casos tão estranhos como este (ou ainda muitos outros de maior gravidade e perigosidade). 


\section{Notas finais}

Como breve nota final refiro que apesar dos esforços e avanços propostos por algumas disciplinas, o trabalho, enquanto campo de pesquisa, é algo que epistemologicamente ainda está em aberto. Na realidade, os efeitos e as consequências do trabalho, ao nível biopsicossocial, são afinal uma "caixa-negra" longe de estar totalmente decifrada. 0 universo do trabalho ainda acarreta alguns enigmas e incorpora um lado obscuro repleto de subjetividades. Na perspetiva de Dejours (2005) o conhecimento científico sobre complexidade humana nas situações de trabalho é ainda incompleto. Porém, julgo que não restam dúvidas sobre a enorme influência que o atual modelo económico dominante exerce nas múltiplas dimensões do trabalho; e isso afeta a saúde mental no trabalho.

Segundo as palavras de Dejours (1999) o nosso modelo de organização social banalizou a injustiça social. Atualmente tudo parece girar em torno do lucro (onde estão incluídas inúmeras formas de exploração e alienação), procrastinando a felicidade humana por causa do trabalho. Volto a sublinhar que se o principal objetivo das organizações não fosse a obtenção do lucro e a acumulação de capital, estes recursos poderiam ser aplicados na melhoria das condições de trabalho (o que naturalmente permitiria reduzir o sofrimento no trabalho) e, principalmente, poderíamos reduzir o tempo que passamos a trabalhar (melhorando a qualidade de vida das nossas sociedades). No teatro laboral contemporâneo a subjetividade e a convivência deveriam ser consideradas variáveis tão importantes quanto a produção e a rentabilidade (de Gaulejac, 2007, p. 288).

É pertinente ter em conta que os riscos ocupacionais (positivos ou negativos) são, de certo modo, omnipresentes e estão em constante mutação. Isto significa que são dinâmicos e nunca são verdadeiramente os mesmos. Todavia, podemos afirmar que os múltiplos riscos no trabalho são uma espécie de "antecâmara" para a ocorrência de falhas, conflitos, acidentes ou doenças (Areosa, 2012a), logo, estes mesmos riscos são sempre passíveis de afetar a segurança e a saúde das pessoas no mundo laboral. A psicodinâmica do trabalho tem contribuído de forma singular para compreender as diversas alterações, bem como as respetivas consequências, associadas às novas formas de organização do trabalho, particularmente aquelas que estão relacionadas com a saúde mental dos trabalhadores. Esta disciplina identificou ainda ruturas significativas que podem conduzir os trabalhadores à morte, já não apenas por doença ocupacional ou acidente de trabalho, mas também por suicídio devido a descompensaç̃es mentais ou psicossociais (Dejours, 2017). Sem dúvida que este é um dos grandes dramas do mundo do trabalho contemporâneo! 


\section{BIBLIOGRAFIA}

Amagasa, T., Nakayama, T., \& Takahashi, Y. (2005). Karojisatsu in Japan : characteristics of 22 cases of work-related suicide. Journal of Occupational Health, 47(2), 157-164.

Amalberti, R. (1996). La conduite des systèmes à risques. Paris : Presses Universitaires de France.

Antunes, R. (2008). Desenhando a nova morfologia do trabalho: As múltiplas formas de degradação do trabalho. Revista Crítica de Ciências Sociais, 83, 19-34.

Areosa, J., \& Carapinheiro, G. (2008). Quando a imagem é profissão : profissões da imagiologia em contexto hospitalar. Sociologia, Problemas e Práticas, 57, 83-108.

Areosa, J., \& Dwyer, T. (2010). Acidentes de trabalho : uma abordagem sociológica. Configurações, $7,107-128$.

Areosa, J. (2010). O risco nas ciências sociais : uma visão crítica ao paradigma dominante. Revista Angolana de Sociologia, 5/6, 11-33.

Areosa, J. (2011). Riscos ocupacionais da Imagiologia : estudo de caso num hospital português. Tempo Social, 23(2), 297-318.

Areosa, J. (2012a). o lado obscuro dos acidentes de trabalho: um estudo de caso no setor ferroviário. Famalicão : Editora Húmus.

Areosa, J. (2012b). O contributo das ciências sociais para a análise de acidentes maiores : dois modelos em confronto. Análise Social, 204, 558-584.

Areosa, J. (2014). As perceções de riscos laborais no sector ferroviário. Sociologia, Problemas e Práticas, 75, 83-107.

Areosa, J. (2017). Compreender os comportamentos para melhorar a segurança. In H. V. Neto, J. Areosa \& P. Arezes (Eds.). Liderança e Participação em Segurança e Saúde no Trabalho (pp. 176-198). Porto : Civeri Publishing.

Areosa, J. (2018a). O trabalho como palco do sofrimento. International Journal on Work Condition, 15, 81-95.

Areosa, J. (2018b). Imagem como profissão - A radiologia enquanto revolução na arte de fazer medicina. Beau Bassin : Novas Edições Acadêmicas.

Bourdieu, P. (1998). Contrafogos. Oeiras : Celta.

Clot, Y. (1995). Le Travail Sans L'homme? Pour une Psychologie des Milieux de Travail et de Vie. Paris : Edition La Découverte.

Dal Rosso, S. (2008). Mais trabalho! A intensificação do labor na sociedade contemporânea. São Paulo : Boitempo.

Damásio, A. (1994). O Erro de Descartes. Emoção, Razão e Cérebro Humano. Mem Martins : Publicações Europa-América.

de Gaulejac, V. (2007). Gestão como doença social : ideologia, poder gerencialista e fragmentação social. São Paulo : Ideias e Letras.

Dejours, C. (1986). Por um novo conceito de saúde. Revista Brasileira de Saúde Ocupacional, 54(14), 7-11.

Dejours, C. (1991). A loucura do trabalho. São Paulo : Cortez Editora. 
Dejours, C. (1998). “ Travailler » n'est pas “ déroger ». Travailler, 1, 5-12.

Dejours, C. (1999). A banalização da injustiça social. Rio de Janeiro : FGV Editora.

Dejours, C. (2005). o fator humano. Rio de Janeiro : FGV Editora.

Dejours, C., \& Bègue, F. (2009). Suicide et travail : Que faire ? Paris : Presses Universitaires de France.

Dejours, C. (2011). Texto Introdutor : Psicopatologia do trabalho - Psicodinâmica do trabalho.

Laboreal, VII(1), 13-16.

Dejours, C., \& Gernet, I. (2011). Trabalho, subjetividade e confiança. In L. I. Sznelwar (Org.), Saúde dos Bancários (pp. 33-42). São Paulo : Publisher Brasil/Editora Gráfica Atitude.

Dejours, C. (2012). Trabalho vivo (Tomo I e II). Brasília : Paralelo 15.

Dejours, C. (2013). A sublimação, entre o sofrimento e prazer no trabalho. Revista Portuguesa de Psicanálise, 33(2), 9-28.

Dejours, C. (2015). Le choix, souffrir au travail n'est pas une fatalité. Montrouge, Fr : Bayard.

Dejours, C. (2016). Organização do trabalho e saúde mental : quais são as responsabilidades do manager? In K. Macêdo et al. (Orgs.). Organização do trabalho e adoecimento : uma visão interdisciplinar (pp. 317-331). Goiânia : Editora PUC Goiás.

Dejours, C. (2017). Psicodinâmica do trabalho : casos clínicos. Porto Alegre - São Paulo : dublinense.

Dekker, S. (2006). Resilience Engineering : Chronicling the Emergence of Confused Consensus. In

E. Hollnagel ; D. Woods \& N. Leveson (Eds.). Resilience Engineering : Concepts and Precepts (pp. 77-92). Aldershot, UK : Ashgate Publishing.

Durkheim, E. (1984). A divisão social do trabalho. Lisboa : Presença.

Facas, E., Duarte, F., Mendes, A. M., \& Araujo, L. (2015). Sofrimento ético e (in)dignidade no trabalho bancário : análise clínica e dos riscos psicossociais. In J. Monteiro, F. Vieira, \& A. M. Mendes (Orgs.). Trabalho e prazer : teoria, pesquisas e práticas (pp. 233-255). Curitiba, PR : Juruá.

Forrester, V. (1997). 0 Horror Económico. Lisboa : Terramar.

Franco, T., Druck, G., \& Seligmann-Silva, E. (2010). As novas relações de trabalho, o desgaste mental do trabalhador e os transtornos mentais no trabalho precarizado. Revista Brasileira de Saúde Ocupacional, 122, 229-248.

Freire, J. (2002). Sociologia do trabalho : uma introdução. Porto : Edições Afrontamento.

Goleman, D. (2006). Inteligência emocional. Lisboa : Sábado.

Hirata, H. (2011). Tendências recentes da precarização social e do trabalho : Brasil, França, Japão. Caderno CRH, 24(1), 15-22.

Hobbes, T. (1983). Leviatã ou Matéria, forma e poder de um estado eclesiástico e civil. São Paulo : Editora Abril.

Kahneman, D. (2012). Pensar depressa e devagar. Lisboa : Temas e Debates.

Kovács, I. (2006). Novas formas de organização do trabalho e autonomia no trabalho. Sociologia, Problemas e Práticas, 52, 41-65.

Marx, K. (1993). Manuscritos económico-filosóficos. Lisboa : Edições 70.

Mendes, A. M. (2018). Desejar, Falar, Trabalhar. Porto Alegre : Editora Fi. 
Miller, G. (1956). The magical number seven, plus or minus two : Some limits on our capacity for processing information. The Psychological Review, 63(2), 81-97.

Molinier, P. (2006). Les enjeux psychiques du travail. Paris : Payot \& Rivages.

Nyberg, A. et al. (2009). Managerial leadership and ischaemic heart disease among employees : the Swedish WOLF study. Occupational and Environmental Medicine, 66, 51-55.

Perrow, C. (1999). Normal accidents : living with high-risk technologies. New Jersey : Princeton University Press.

Rasmussen, J. (1997). Risk management in a dynamic society : A modeling problem. Safety Science, $27,183-213$.

Reason, J. (1990). Human error. Cambridge : Cambridge University Press.

Rolo, D. (2018). O trabalho : entre prazer e sofrimento. TMQ - Techniques, Methodologies and Quality, número especial, 28-38.

Rousseau, J-J. (1989). O contrato social. Mem-Martins : Publicações Europa-América.

Sennett, R. (2001). A corrosão do carácter : as consequências pessoais do trabalho no novo capitalismo. Lisboa : Terramar.

Sennett, R. (2006). A cultura do novo capitalismo. Rio de Janeiro : Editora Record.

Simons, D., \& Chabris, C. (2010). The Invisible Gorilla : How our intuitions deceive us. New York : Crown Publishers.

Smith, A. (1979). Investigação sobre a natureza e as causas da riqueza das nações. São Paulo : Abril Cultural.

Standing, G. (2014). o precariado - a nova classe perigosa. Lisboa : Editorial Presença.

Sznelwar, L. I., Uchida, S., \& Lancman, S. (2011), A subjetividade no trabalho em questão. Tempo social, 23(1), 11-30.

Sznelwar, L. I. (2015). Quando trabalhar é ser protagonista e o protagonismo no trabalho. São Paulo : Blucher.

Taleb, N. (2008). O Cisne Negro - O impacto do altamente improvável. Amadora : Dom Quixote.

Wandelli, L. V. (2015). Da psicodinâmica do trabalho ao direito fundamental ao conteúdo do próprio trabalho e ao meio ambiente organizacional saudável. Revista Eletrônica do Curso de Direito da UFSM, 10, 193-217.

Weber, M. (2001). A ética protestante e o espírito do capitalismo. Lisboa : Editorial Presença.

\section{NOTAS}

1. Porém, a forma de não produzirmos cada vez melhor está longe de ser inocente. Provavelmente o leitor iria sorrir com ironia se eu lhe dissesse que uma lâmpada (similar às que tem em sua casa) poderia durar mais de cem anos. Mas pode! E não é mera ficção, pois existe uma lâmpada em Livermore (Califórnia, EUA) que tem atualmente cerca de 117 anos de existência e continua a funcionar. Esta situação intrigou um empresário de Barcelona - Benito Muros - e levantou-lhe a seguinte questão: se há mais de cem anos existiam técnicas e tecnologias suficientes para fazer uma lâmpada durar tanto tempo, porquê que hoje "já não somos capazes disso"? É neste contexto que entramos na noção de "obsolescência programada", a qual está 
intimamente relacionada com o capitalismo atual. Na realidade, a obsolescência programada é uma prática fraudulenta, efetuada por algumas empresas, dado que fabricam produtos para durarem pouco tempo. Obviamente que o que está por trás desta política é vender mais e, por consequência, lucrar mais. O nosso modelo económico atual, baseado no consumo, tem de vender em grandes quantidades para sobreviver, logo, se os produtos durassem muito tempo as vendas cairiam de forma drástica. É por isso que atualmente se produz, de forma intencional, quase tudo com um ciclo de vida limitado, quer seja uma simples lâmpada doméstica, quer sejam automóveis, roupas, eletrodomésticos ou computadores. Todavia, este tipo de estratégia utilizada à escala global tem diversos efeitos negativos (alguns porventura incalculáveis), tanto ao nível do desperdício de recursos (os quais são suscetíveis de afetar gravemente o meio ambiente), como no âmbito dos direitos humanos, laborais e da qualidade de vida individual e coletiva (porque, por exemplo, obrigamos as pessoas a trabalhar mais e em piores condições quando não há necessidade disso).

2. A escritora Viviane Forrester (1997) refere ironicamente uma terceira "categoria de pessoas": os supérfluos. São indivíduos que estão fora do mercado de trabalho e que a economia os pretende rotular como nefastos para a sociedade. Paralelamente à questão da dualização do mercado de trabalho existem autores que não partilham esta visão determinista do mundo do trabalho, referindo que ele é bem mais complexo e diversificado do que esta visão dualista traduz (Kovács, 2006).

3. A propósito destas duas situações surgiu o termo japonês karoshi para se referir aos trabalhadores que morrem por causa do excesso de trabalho, normalmente após longas horas sem interrupção para descansar. Paralelamente, também no Japão, foram detetados alguns casos de trabalhadores que se suicidaram devido ao excesso de trabalho. Esta situação foi apelidada por karojisatsu (Amagasa et al., 2005). Os autores colocam como hipótese o seguinte: longas jornadas de trabalho, sobrecarga de trabalho e níveis reduzidos de apoio social podem causar depressão, a qual, por sua vez, pode conduzir ao suicídio. Estes são alguns dos traços comuns nos casos de suicídio analisados por esta pesquisa (Amagasa et al., 2005).

4. Ao longo do texto irei apresentar múltiplos casos que são fonte de sofrimento no trabalho, mas creio que não é difícil imaginar diversas situações que, inversamente, podem gerar prazer no trabalho. Lembremos, por exemplo, uma equipa de cirurgia que conclui com sucesso uma intervenção, cujo paciente estava em risco de vida; um jogador de futebol que marca o único golo na final de uma competição importante e sente a euforia de milhares de adeptos; ou um agricultor com sensibilidade suficiente para se orgulhar ao ver florescer os frutos do seu trabalho (Areosa, 2018a).

5. Pretendo deixar claro que não é minha intenção efetuar uma apologia do trabalho em detrimento do lazer, até porque me parece que o equilíbrio entre ambos será, em princípio, mais vantajoso em diversos níveis (incluindo na saúde mental). Sob o formato de analogia, evoco, neste contexto, as palavras de Aristóteles, onde o filósofo grego apontava que a felicidade do Homem (provavelmente a finalidade última da nossa existência e a maior de todas as virtudes) estaria no meio-termo, no ponto médio entre o excesso e o defeito, ou seja, entre dois extremos (neste caso, metaforicamente, no equilíbrio entre o trabalho e o lazer).

6. A subjetividade é um dos aspetos centrais na abordagem da psicodinâmica do trabalho. Segundo Dejours, a afetividade é a base da subjetividade. Neste contexto, entende-se por afetividade a forma como o corpo vivencia o contato com o mundo exterior. Menosprezar ou desconsiderar a afetividade e a subjetividade é negar no homem a sua própria humanidade. "O essencial da subjetividade é da categoria do invisível. O sofrimento não se vê. Tampouco a dor. 0 prazer não é visível. Esses estados afetivos não são mensuráveis. São vivenciados de «olhos fechados». O fato de que a afetividade não possa jamais ser medida nem avaliada quantitativamente, de que ela pertença ao domínio das trevas, não justifica que se lhe negue a realidade nem que se despreze os que dela ousam falar de modo obscurantista. Ninguém ignora o 
que sejam o sofrimento e o prazer, e todos sabem que isso só se vivencia integralmente na intimidade da experiência interior" (Dejours, 1999, p. 29).

7. Segundo as palavras do autor: "A psicodinâmica do trabalho estuda as condições de articulação das inteligências singulares, na coordenação das atividades, no nível da organização do trabalho como um todo ou de um segmento dessa organização. Nesse ponto, encontramos então a distância entre a organização do trabalho prescrito e organização do trabalho real. Este último toma o lugar da distância inicial entre tarefa e atividade, de modo que passamos do singular ao plural, do individual ao coletivo, do solipsismo à intersubjetividade, da inteligência astuciosa à cooperação" (Dejours, 2005, p. 57).

8. Em determinadas organizações as pessoas são imaginadas como uma espécie de robots invulneráveis a alterações de ordem bio-psicossociológicas, pois surge constantemente reforçada a "fantasia" de que existe um homem quimérico, um trabalhador irrepreensível que não é suscetível de errar ou de estar momentaneamente desatento, que nunca pode estar cansado e que trabalha sempre com o mesmo ritmo (sem acelerar ou ficar mais lento), que não adoece nem tem alterações de humor, que não tem problemas familiares ou conflitos com os colegas e hierarquias. Em resumo, idealizam um trabalhador perfeito; infelizmente esse trabalhador não existe no mundo real!

9. Um outro exemplo marcante desta situação é relatado no reputado livro de Daniel Simons e Christopher Chabris (2010), onde os participantes de uma pesquisa estão tão concentrados num determinado objetivo (contar o número de passes que os jogadores de basquetebol com camisola branca fazem, ignorando os de camisola preta) que a maioria não consegue visualizar um alegado gorila que surge inesperadamente no meio do ringue.

10. Acedido em 05/02/2018, através do link: http://www.publico.pt/sociedade/noticia/umsuicidio-no-trabalho-e-uma-mensagem-brutal-1420732

11. Alguns autores complementam esta noção ao afirmarem que existe já uma quarteirização, isto é, são "empresas contratadas para gerir contratos com as terceiras, caracterizando a cascata de subcontratação" (Franco et al., 2010, p. 233). É pertinente acrescentar que a expansão da subcontratação no mundo do trabalho tem sido um fator bastante notório em alguns países, nomeadamente no Brasil, na França e no Japão (Hirata, 2011).

12. Podemos definir a empatia como uma capacidade ou habilidade para conseguir colocar-se no lugar do outro. No fundo, é tentar antever ou compreender aquilo que os outros estão a sentir. Demonstrar empatia oferece diversas vantagens no campo das relações humanas e nas interações sociais. Inversamente, a ausência de empatia é reveladora de alguma falha emocional; a título de exemplo, em casos extremos encontramos este tipo de falhas em criminosos psicopatas, violadores e pedófilos (Goleman, 2006).

\section{RESUMOS}

A organização do trabalho está diretamente relacionada com a forma como os trabalhadores percecionam os múltiplos aspetos (positivos e/ou negativos) relacionados com a sua atividade laboral. A abordagem da psicodinâmica do trabalho trata precisamente das consequências do trabalho na saúde mental dos trabalhadores, nomeadamente no prazer que suscita ou no sofrimento que produz. É por esse motivo que nos parece pertinente debater a organização do trabalho a partir da perspetiva da psicodinâmica do trabalho, a qual tem oferecido inúmeros conhecimentos sobre esta complexa realidade. 
La organización del trabajo está directamente relacionada con el modo como los trabajadores perciben los múltiples aspectos (positivos y/o negativos) relacionados con su actividad laboral. El enfoque de la psicodinámica del trabajo aborda precisamente las consecuencias del trabajo en la salud mental de los trabajadores, especialmente en el placer que suscita o en el sufrimiento que produce. Es por ese motivo que nos parece pertinente debatir la organización del trabajo a partir de la perspectiva de la psicodinámica del trabajo, la cual ha ofrecido innumerables conocimientos sobre esta compleja realidad.

L'organisation du travail est en lien direct avec la façon dont les travailleurs perçoivent les aspects multiples (positifs et/ou négatifs) de leur activité de travail. L'approche de la psychodynamique du travail traite, précisément, des conséquences du travail sur la santé mentale des travailleurs, notamment le plaisir et la souffrance qu'il peut générer. Pour cette raison, il nous paraît pertinent de discuter l'organisation du travail à partir de l'approche de la psychodynamique du travail et de ses nombreuses contributions à la connaissance et à la compréhension de cette réalité complexe.

The organization of work is closely related to how employees perceive the multiple aspects (either positive or negative) of their work activity. The approach of psychodynamics of work deals precisely with the effects of work on the workers' mental health, in particular with the pleasure or pain it produces. That is why we consider it appropriate to discuss the organization of work from the perspective of the psychodynamics of work, which gives significant knowledge contributions for this complex reality.

\section{ÍNDICE}

Palabras claves: trabajo, organización del trabajo, psicodinámica del trabajo

Keywords: work, organization of work, psychodynamic of work

Palavras-chave: trabalho, organização do trabalho, psicodinâmica do trabalho

Mots-clés: travail, organisation du travail, psychodynamique du travail

\section{AUTOR}

\section{JOÃO AREOSA}

Investigador integrado no CICS-NOVA (Universidade Nova de Lisboa) ; Professor Convidado no Instituto Politécnico de Setúbal (ESCE-IPS) ; Escola Superior de Ciências Empresariais (ESCE), do Instituto Politécnico de Setúbal (IPS), Campus do IPS - Estefanilha, 2914-503 Setúbal ; joao.areosa@esce.ips.pt 